\title{
The curious career of Dr. Monica Kidd
}

\author{
Cite as: CMAJ 2017 January 9;189:E28-9. doi: 10.1503/cmaj.160625
}

What I remember is the tips of his fingers calloused from too many job sites, too many winters. His blood spreading over a sheet. Someone whispering.

Couldn't afford the time off work to get the surgery.

\section{A sick wife and a kid at home.}

The way he died because he was poor.

- Kidd M. Risk factors for hemorrhagic pancreatitis. In: Handfuls of Bone.

Kentville (NS): Gaspereau Press; 2012.

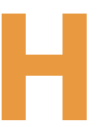

ers is a curious CV, the CV of a curious mind. She has worked as a seabird biologist, as a radio journalist and, now, as a family doctor and associate professor of medical humanities. Through it all, Monica Kidd has written three volumes of poetry, two novels, numerous essays, a book-length exploration of the lives of her Slovakianimmigrant great-grandparents, a couple of short films and countless radio scripts.

"I'm that person to whom something has not happened unless I've written about it," she says. "Things wash over me too quickly, life moves really fast. I need to write. I kind of feel dead when I don't."

Now 44, Kidd grew up in the farming community of Elnora in central Alberta, where her parents ran the local store. Early on, she decided she wanted to go to university, although she wasn't quite sure what that entailed.

“In a town of 200, there weren't many examples of what one does with a university education - except for the local doctor. So I thought, I'll do that."

At the University of Calgary, she was the kid in the candy store.

"It blew my mind with all the different things you could think about, all the adventures you could have. And very quickly I came to see the people gunning for medical school were very goal-directed, more interested in grades than actual

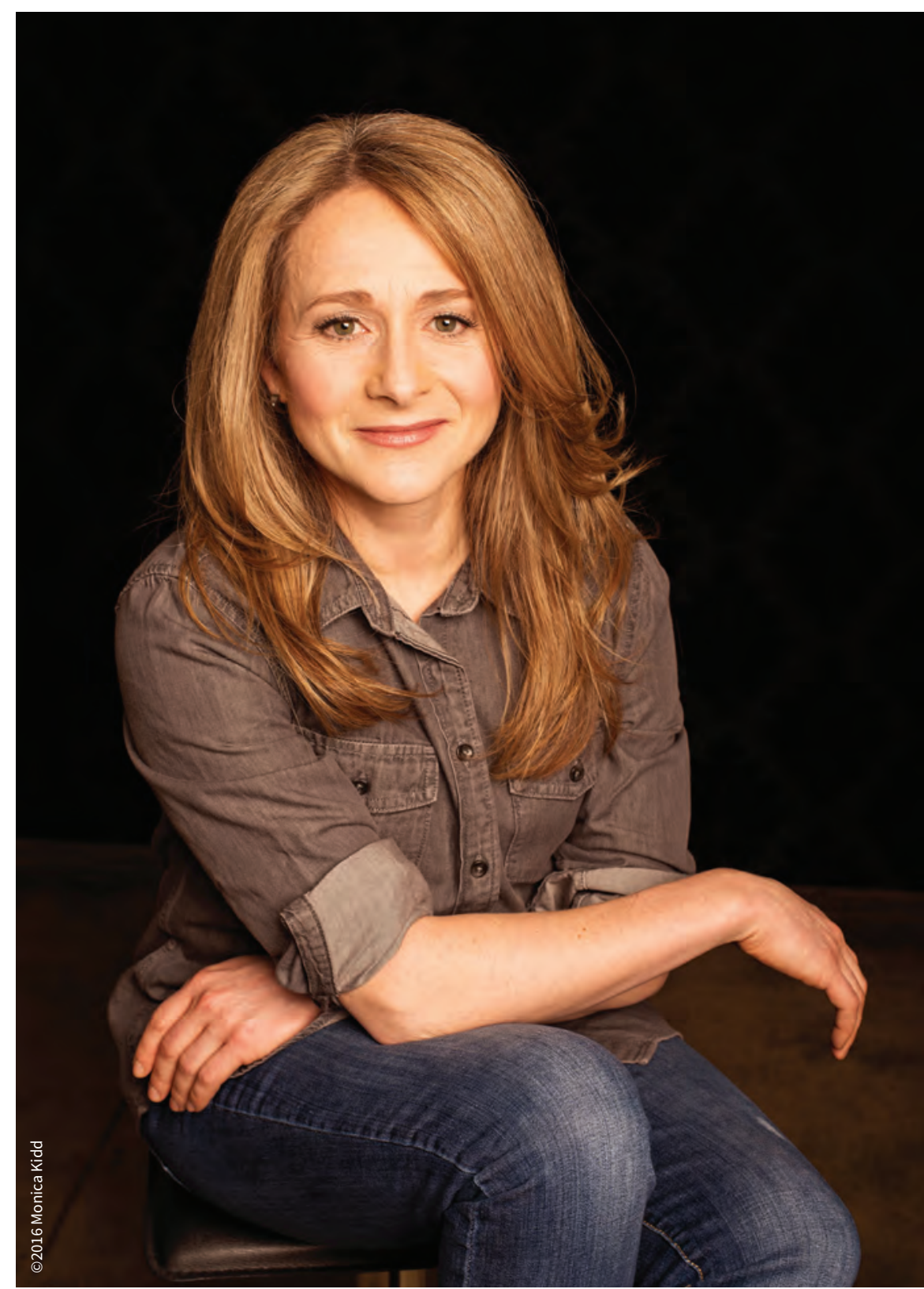

Monica Kidd has worked as a seabird biologist, a CBC journalist and, now, a family doctor. The one constant is her need to write: poetry, novels, essays, films and memoirs.

learning, and I thought I wasn't interested in that game, thank you."

Instead, after her undergrad, Kidd headed to Queen's for a masters of science in evolutionary biology. It was a pro- gram that emphasized mitochondrial genetics.

"And here I was, in this weird position of having blood samples of seabirds sent to me from around the world, but being a 
prairie girl, having no idea what these birds looked like."

So Kidd took a leave of absence from her graduate work to study guillemots, lesser known cousins of the puffin, on the remote Gannet Islands, 40 kilometres off the coast of Labrador. "Amazing," she says of that experience.

"I was completely sideswiped by Newfoundland and Labrador. It was so electric, it was like starting life over again."

Unable to find a permanent position as a seabird biologist, Kidd plunged into another of her passions - making radio documentaries. Eventually, she landed a job with CBC Radio in St. John's.

"I love asking questions. I love listening to people. I love mixing the sounds, and I love the layers of meaning in sounds."

Kidd was on air for seven years, eventually working her way up to being the corporation's national science reporter. But after some institutional upheaval at the $C B C$, she knew it was time for a change. It wasn't easy. And it still isn't. "I miss radio like a phantom limb."

As a journalist, she had done many stories on the doctor shortage. She decided, finally, to pursue her childhood ambition. At age 32, she enrolled in medical school at Memorial University, St. John's. "It was totally terrifying."

Twelve years later, Kidd is back in Alberta with her husband, fellow careerjumper Steve Hunt, a mechanical engineer turned orthopedic surgeon. They have three young children.

These days, in addition to her family practice, Kidd teaches medical humanities at the University of Calgary.

"For me, it's been a very logical career path," she laughs. "Although from the outside, I can see it might look different."

It's in her teaching that Kidd's seemingly disparate interests begin to come together.
"But I guess I come to it more as a writer and a journalist than as a physician. I believe story is really important to a person's overall existence in the world, including their [sic] health. And having a mind supple enough to appreciate the different ways people describe things is really important diagnostically."

And that, to Kidd, starts with listening. She alludes to a classic 1984 study that found that, on average, physicians interrupt patients every 18 seconds. ${ }^{1}$ (Another study, 17 years later, clocked primary care residents at 12 seconds. ${ }^{2}$ )

"Something happens in the medical acculturation process for a lot of people that says that patients' stories don't matter. What matters is fixing the problem, and the problem is very narrow and specific - and I don't need to get involved in the rest of your life in order to do that.

"But I would hope that's not the only way to practise medicine, because I don't think that's very gratifying for patient or physician. We've all been regarded as specific problems and we've all been regarded as whole human beings, and I don't think there's much question which is better.

"And so, in my teaching, I try to get across the importance of story and to challenge the standard scientific tradition of what is a fact and what is a truth. I want to get students to question whether physicians are expected to know the truth or whether they should constantly be questioning their own and other people's understanding of truth."

In this, Kidd believes, the humanities are a vital tool.

"As a writer, I don't have to work very hard to listen for people's points of view, to understand the metaphors they use and notice the holes they leave in their stories. Those are pretty natural things for my ear. And I think a lot of that can be learned from art."
That said, medical humanities remain a tough sell.

"Each time you want to take an hour of cardiac physiology away from a program, there's a great hew and cry, especially when you're replacing it with the airyfairy stuff. So the opportunities are not huge for curriculum time, but I've managed to eke out a couple of hours."

In probing Kidd about her writing, an interviewer once asked her the best piece of advice she'd ever received. She replied that it was "to ask people what they're most afraid of." So I ask her that.

"Maybe losing my curiosity," she says after a thoughtful pause. "Because if there's one thing that underpins absolutely everything I've done since I've been self-aware, it's been my curiosity - before money, before advantage, it's been curiosity. But I think you can get tired and stop being curious. Sometimes people just settle, and they're not really interested in doing new things. I hope that never happens."

In Kidd's case, it hardly seems likely. Recently, she broke ground on an ambitious third novel about American draftresisters who flee to Newfoundland during the Vietnam War. And in February 2017, in a reprise of sorts of her days on the Labrador coast, she will serve as an onboard naturalist on a Norwegian expedition to Antarctica.

"I don't know where that's going to lead," she says. "We'll have to see."

\section{David McDonald}

Journalist, Ottawa, Ont.

\section{References}

1. Beckman HB, Frankel RM. The effect of physician behavior on the collection of data. Ann Intern Med 1984;101:692-6.

2. Rhoades DR, McFarland KF, Finch WH, et al. Speaking and interruptions during primary care office visits. Fam Med 2001;33:528-32. 